\title{
European Union Competent Authority
}

National Cancer Institute

\section{Source}

National Cancer Institute. European Union Competent Authority. NCI Thesaurus. Code C142544.

The managing organization, approved by a European Member State government, responsible for ensuring compliance with national regulations. 